\title{
Behandling av premature - hvem skal ta avgjørelsen?
}

Dagens retningslinjer for behandling av premature født på grensen av levedyktighet legger til rette for systematiske forskjeller og ulikt behandlingstilbud. Dette er etisk og medisinsk sett problematisk. Hvem skal fatte beslutningen der det ikke finnes et åpenbart svar?

I Tidsskriftet nr. 1/2016 har Thor Willy Ruud Hansen \& Reidun Førde en grundig gjennomgang av det medisinske og etiske grunnlaget for behandlingsbeslutninger ved ekstrem prematuritet (1). Det ble i fjor, i en nasjonal spørreundersøkelse, påvist forskjeller mellom landets føde- og barneavdelinger i behandlingstilbudet til premature. Det synes å foreligge full enighet om å behandle alle barn fra uke 24, i uke 23 er det ulik praksis, og noen få åpner for aktiv behandling i uke 22 (2).

$\AA$ ha en absolutt grense basert på svangerskapslengde er utfordrende. Kjønn, flerlingsvangerskap og veksthemning kan eksempelvis ha stor betydning for prognosen. Internasjonalt snakker man om en "gråsone» mellom svangerskapsuke 22 og svangerskapsuke 25 , hvor risikoen for død og alvorlig skade gjør at det er rom for å stille spørsmål om hvorvidt livreddende behandling er til barnets beste (3). Det foreligger her uenighet blant fagfolk som alle argumenterer ut fra etiske grunnprinsipper. Kjernespørsmålet blir da: Hvem eier beslutningen?

\section{Foreldreautonomi}

Ved fundamental tvil om hvilken medisinsk behandling som er til barnets beste, slår foreldreautonomiprinsippet inn (4). Når ingen valg fremstår som åpenbart best, har ikke nødvendigvis leger bedre forutsetning for å treffe beslutninger enn foreldrene. Likevel hevder Ruud Hansen \& Førde at det «ikke (er) foreldrenes ansvar å fatte liv-eller-dødbeslutninger». Dette begrunnes ut fra hensynet til foreldrene selv: Mange ønsker seg fritatt fra beslutningsansvar. Samtidig fremhever de viktigheten av en sensitiv dialog der foreldrene blir hørt om hva de tenker.

For å kunne delta i beslutningen er foreldrene helt prisgitt legenes informasjon om prognoser og forventet behandlingsbyrde. De må også inviteres inn i en dialog rundt hvilke valg som i dag anses å være innenfor det medisinsk og etisk forsvarlige. Dette definerer foreldrenes handlingsrom, hvor deres livssyn og verdier bør veie mer enn den enkelte leges holdning. Selv om dette er tunge beslutninger som noen foreldrene helst vil slippe å ta, vil andre mene at beslutningen bør ligge hos dem $(5,6)$.

Det er krevende å få til dialog der foreldrene kan gi uttrykk for sine verdier, også hvis de strider mot legens. Denne type samtaler fortjener økt oppmerksomhet og mer trening (7). Fra nyfødtleger argumenteres det ofte med at man nærmest alltid blir enig med foreldrene. I lys av de nasjonale forskjellene spør vi oss om det er sånn at foreldrenes holdninger er geografisk bestemt, eller om vi undervurderer betydningen av helsepersonellets egne holdninger og hva slags informasjon man gir foreldre $\mathrm{i}$ en sårbar situasjon.

\section{Prioriteringshensyn, også for de minste}

Ruud Hansen \& Førde argumenterer for at man i utgangspunktet bør ha en aktiv holdning til livreddende behandling ved svanger-

\section{«Ved fundamental}

\section{tvil om hvilken medi- sinsk behandling som er til barnets beste, slår foreldreautonomi- prinsippet inn»}

skapsuke 23 og svangerskapsuke 24 . I lys av nyere studier, som viser økt overlevelse ved 22 uker, er det bare et tidsspørsmål før fortvilte foreldre og grensesprengende nyfødtleger vil ønske aktiv behandling for barn født i uke 22. Andre godt informerte foreldre vil kunne ha et ønske om å avstå fra behandling ved svangerskapsuke 24 hvis øvrige prognostiske markører peker i negativ retning. Vil det for helsepersonell være lettere å etterkomme et ønske om behandling heller enn å avstå fra behandling?

Det overordnede ansvar for hvilket behandlingstilbud som skal tilbys de enkelte pasientgrupper, hviler på helsemyndighetene. Vi er enige med Dag Bratlid i hans kommentar om at prioriteringshensyn fra helsemyndighetene også må gjelde de ekstremt premature (8). Velger man å satse på livreddende behandling ned mot levedyktighetsgrensen, har man også et ansvar for å legge til rette for at de barna man redder, får et best mulig liv - uansett senskader.

\section{Mot et likeverdig tilbud}

Vi mener at en beslutning om igangsetting av livreddende behandling før svangerskaps- uke 25 bør tas etter en individuell vurdering, basert på familiens ønsker og i en prosess bygd på samvalg (shared decision-making) (9). Foreldrene bør få være med og påvirke prosessen i den grad de ønsker det - og de skal også kunne frasi seg valget. Muligheten for gjentatte samtaler med et koordinert behandlingsteam står sentralt.

Diskusjonen rundt dette temaet har pågått i flere tiår, og det er lite sannsynlig at man vil oppnå medisinsk og etisk konsensus. Åpne prosesser, der beslutningen tas i fellesskap, sammen med dem som skal leve videre med konsekvensene av den, mener vi er et viktig skritt i riktig retning. Om alle norske sykehus følger denne tankegangen, vil det også bli et likeverdig og rettferdig tilbud.

Janicke Marita Syltern
janickesyl@hotmail.com
Ragnhild Støen
Lars Ursin
Berge Solberg

Janicke Syltern (f. 1973) er spesialist i barnesykdommer, overlege ved Barn og Nyfødt intensiv ved St. Olavs hospital og medlem av klinisk etikkomité, St. Olavs hospital.

Forfatter har fylt ut ICMJE-skjemaet og oppgir ingen interessekonflikter.

Ragnhild Støen (f. 1962) er spesialist i barnesykdommer, avdelingssjef ved Avdeling Nyfødt intensiv ved St. Olavs hospital og førsteamanuensis ved Institutt for laboratoriemedisin, barne- og kvinnesykdommer ved Norges teknisk-naturvitenskapelige universitet.

Forfatter har fylt ut ICMJE-skjemaet og oppgir ingen interessekonflikter.

Lars Øystein Ursin (f. 1971) har en ph.d.-grad i filosofi. Han forsker i medisinsk etikk ved Institutt for samfunnsmedisin, Norges teknisknaturvitenskapelige universitet.

Forfatter har fylt ut ICMJE-skjemaet og oppgir ingen interessekonflikter.

Berge Solberg (f. 1969) er professor i medisinsk etikk ved Institutt for samfunnsmedisin, Norges teknisk-naturvitenskapelige universitet, og sekretær i klinisk etikkomité ved St. Olavs hospital.

Forfatter har fylt ut ICMJE-skjemaet og oppgir ingen interessekonflikter. 


\section{Litteratur}

1. Hansen TW, Førde R. Premature og behandlingsgrenser. Tidsskr Nor Legeforen 2016; 136: 45-7.

2. Nasjonalt råd for kvalitet og prioritering. Behandling og oppfølging av ekstremt premature barn. http://www.kvalitetogprioritering.no/saker/ behandling-og-oppf\%C3\%B8lging-av-ekstremtpremature-barn (18.3.2016).

3. Leuthner SR. Borderline viability: controversies in caring for the extremely premature infant. Clin Perinatol 2014; 41: 799-814.

4. Lov om pasient- og brukerrettigheter (pasient og brukerrettighetsloven). LOV-1999-07-02-63. https://lovdata.no/dokument/NL/lov/ 1999-07-02-63 (18.3.2016).

5. Vandvik IH. Førde R. Ethical issues in parental decision-making. An interview study of mothers of children with hypoplastic left heart syndrome. Acta Paediatr 2000; 89: 1129-33.

6. McHaffie HE, Lyon AJ, Hume R. Deciding on treatment limitation for neonates: the parents' perspective. Eur J Pediatr 2001; 160: 339-44.

7. Stokes TA, Watson KL, Boss RD. Teaching antenatal counseling skills to neonatal providers. Semin Perinatol 2014; 38: 47-51

8. Bratlid D. Premature og behandlingsgrenser etikk og prioritering. Tidsskr Nor Legeforen 2016; 136: 618-9.

9. Elwyn G, Frosch D, Thomson R et al. Shared decision making: a model for clinical practice. J Gen Intern Med 2012; 27: 1361-7.

Mottatt 18.3. 2016, første revisjon innsendt 4.4.

2016, godkjent 5.4. 2016. Redaktør: Ketil Slagstad

Publisert først på nett 